\title{
Efektifitas Perangat Pembelajaran Inkuiri Terintegrasi Kearifan Lokal Terhadap Keterampilan Berpikir Kritis Mahasiswa
}

\author{
Hunaepi, Laras Firdaus, Taufik Samsuri, Endang Susantini, Raharjo \\ hunaepi@ikipmataram.ac.id, larasfirdaus@ikipmataram.ac.id, taufiksamsuri@ikipmataram.ac.id, \\ endangsusantini@unesa.ac.id, raharjo@ikipmataram.ac.id \\ Prodi Pendidikan Biologi, Universitas Pendidikan Mandalika, \\ Prodi Pendidikan Biologi, Universitas Negeri Surabaya
}

\section{The Effectiveness of Inquiry Learning Tools with Local Wisdom Integration Towards Students' Critical Thinking Skills}

\begin{abstract}
This study aims to improve the ability of the inquiry learning tool integrated with local wisdom in improving students' critical thinking skills. There were four classes of experiments to determine entitlements in research results, which were also designed as pretest-posttest groups. The sample in this study were 100 students, who were divided into four groups using saturated sampling technique. The critical thinking skills test consisted of 6 items which were declared valid. The results showed that the thinking skills of students before and after learning the software were significantly different ( $p<0.05$ ). These results indicate that the learning tools developed effectively improve students' critical thinking skills, although the average increase in each indicator is in the medium category. This condition indicates that for further research it is necessary to develop an inquiry model that is integrated with local wisdom.
\end{abstract}

Keywords: Inquiry, Local Wisdom, Critical Thinking

Article Info

Received date: 26 Agustus $2020 \quad$ Revised date: 7 September 2020 Accepted date: 24 September 2020

\section{PENDAHULUAN}

Pengetahuan ilmiah dan teknologi telah tumbuh secara eskponensial dan berkembang secara pesat di era revolusi industry 4.0. Kondisi ini mengharuskan setiap mahasiswa mampu menginternalisasikan pengetahuan, berpikir secara logis, kritis, kreatif, inovatif, membuat keputusan dan memecahkan masalah. Keterampilan-keterampilan tersebut harus dimiliki agar mahasiswa melek akan sains. Melek sains membutuhkan proses pembelajaran yang mengarahkan mahasiswa untuk berpikir dan melakukan penyelidikan dengan menggunakan metode ilmiah. Sistem berpikir menjadi salah satu kompetensi untuk dapat menjawab tantangan tersebut (Alghamdi and Hassan, 2016).

Tuntutan sistem berpikir secara konprehensif dalam pendidikan bertujuan untuk mewujudkan manusia yang berkualitas, terampil dan professional (Slamet, et. al., 2014). Beberapa keterampilan yang harus dimiliki oleh pebelajar antara lain berpikir kritis, kreatif, inovatif, keterampilan kolaborasi dan komunikasi (Partnership for $21^{\text {st }}$ Century Skills, 2015). Prayogi, Yuanita \& Wasis, (2018); Wasis, (2016) Keterampilan berpikir kritis sebagai salah satu keterampilan berpikir tingkat tinggi, dan menjadi salah satu kompetensi yang harus dimiliki oleh pebelajar untuk dapat beradaptasi dengan perkembangan sains dan teknologi abad 21. Dengan keterampilan berpikir kritis seseorang dapat mengetahui kekutan dan kelemahan suatu perkembangan (Sari, et.al., 2019).

Berpikir kritis merupakan pemikiran rasional reflektif yang terfokus untuk memutuskan apa yang harus dilakukan dan apa yang harus dipercaya (Enis, 1993) sehingga mendapatkan penguatan dari informasi yang didapatkan (Amin et.al, 2014). Cekin, (2015) untuk dapat beradaptasi dengan perubahan setiap pebelajar harus memiliki kemampuan berpikir kritis (Ennis, 1993) dengan kemampuan tersebut pebelajar dapat mengevaluasi informasi untuk dapat mendapatkan keputusan secara masuk akal, dan rasional. Murawski, (2014) menyebutkan bahwa Berpikir kritis berarti meninjau kembali ide-ide yang dihasilkan, membuat keputusan tentatif tentang tindakan apa yang paling baik dalam memecahkan masalah atau keyakinan tentang masalah yang paling masuk akal dan kemudian mengevaluasi dan menyempurnakan solusi atau keyakinan, yang melibatkan, (Bassham, et.al., 2011) keterampilan 
Efektifitas Perangat Pembelajaran Inkuiri Terintegrasi Kearifan Lokal Terhadap Keterampilan Berpikir Kritis Mahasiswa (Hunaepi, Laras Firdaus, Taufik Samsuri, Endang Susantini, Raharjo)

kognitif. Herdiana,et.al, (2019) Pemikiran kognitif dan disposisi berpikir kritis memiliki peran dalam menganalisis memecahkan masalah yang dihadapi.

Beberapa hasil penelitian menunjukkan keterampilan berpikir kritis yang dimiliki peserta didik berdampak positif terhadap kemandirian dalam mengembangkan pengetahuan. Taghva, et.al, (2014) keterampilan berpikir kritis yang dimiliki guru memiliki hubungan yang signifikan dengan prestasi peserta didik. Hadi, Susantini, \& Agustini, (2018) keterampilan berpikir kritis berkolerasi positif dengan pemahaman konsep peserta didik. Faradia, Fuzi, and Vitoria, (2017); Komariyah \& Laili, (2018); Fazriyah, Supriyanti, and Rahayu, (2017) berpikir kritis berpengaruh signifikan terhadap hasil belajar sains. Sedangkan Quitadamo, et.al., (2008) keterampilan berpikir kritis berpengaruh pada prestasi akademik siswa. Siswa dengan keterampilan berpikir kritis tinggi memiliki kemampuan pemecahan masalah yang lebih tinggi dari pada siswa dengan keterampilan berpikir kritis rendah. Temuan-temuan tersebut menunjukkan bahwa keterampilan berpikir kritis sangat penting untuk dibelajarkan (Mulyanto, Gunarhadi, \& Indriayu, 2018).

Kondisi ini mengisyaratkan bahwa berpikir kritis menjadi sangat penting untuk dibelajarkan dalam dunia pendidikan. Herdiana, et.al, (2018) Keterampilan berpikir kritis sebagai modal intelektual yang merupakan bagian fundamental dari kedewasaan manusia sehingga penting untuk diajarkan di setiap tingkat pendidikan. Mimbs, (2005); Mahapoonyanont, (2010) mengajarkan ataupun membelajarkan berpikir kritis kepada mahasiswa bertujuan agar mahasiswa mampu membangun pengetahuan sendiri melalui proses inkuiri serta mampu memecahkan masalah dan membuat keputusan dengan lebih baik. Wheelihan, (2011); Changwong, (2018) keterampilan berpikir kritis sebagai proses mental dan kunci keberhasilan dalam pembelajaran.

Upaya yang telah dilakukan selama ini dalam proses pembelajaran untuk meningkatkan keterampilan berpikri kritis, diantaranya hasil penelitian (Prayogi, et.al, 2017) penerapan pembelajaran Critical-Inquiry-Based-Learning (CIBL) dapat menigkatkan keterampilan berpikir kritis mahasiswa. (Putra, Prayitno, \& Mariadi, 2018) terdapat berbedaan tingkat berpikir kritis antara Guided inquiri dan INSTAD, siswa yang dibelajarkan dengan Instad memiliki CT lebih tinggi dari pada Guided inquiri. Irwan, Mariadi, dan Dwiastutik, (2019) pengembangan modul ekologi berbasis inkuri terbimbing lebih baik dalam pemberdayaan keterampilan berpikir kritis dibandingkan dengan buku teks yang digunakan sekolah. Selanjutnya Wahyudi, et.al., (2018) Penerapan model pembelajaran Inquiry Creative Prosess (ICP) efektif untuk meningkatkan CT. Masek and Yamin (2011) dalam tinjauan literatur yang dikebangkanya menyimpulkan bahwa proses pembelajaran menggunakan Problem Based Learning (PBL) secara teoritis mendukung berpikir kritis, dalam bukti empiris tidak meyakinkan dalam menjelaskan efek PBL pada kemampuan berpikir kritis, dan bukti menunjukkan bahwa proses pembelajaran PBL membutuhkan waktu lama untuk menumbuhkan kemampuan berpikri kritis siswa. Namun dalam pelaksanaan pembelajaran masih menunjukkan kelemahan antara lain; 1) keterbatasan waktu untuk melakukan karya ilmiah dalam pembelajaran IPA, dan 2) kuranyanya mengakomodir CT siswa akademik tingkat rendah karena fokus pada penerapan model pembelajaran, selain itu, pada hasil penelitian indikator evaluasi, concluding, self regulate masih tergolong rendah bahkan dalam penelitian Wahyudi dan Syaipul belum mengakomodir indikator CT self regulate.

Untuk mengembangkan keterampilan berpikir kritis, mahasiswa perlu terlibat aktif dalam pembelajaran dan tatap muka dengan situasi kehidupan nyata (Rohmawatiningsih, Rachman \& Kodama, 2018). Dalam KKNI dan Permenristek 2015 dinyatakan bahwa biologi merupakan suatu proses penemuan atau inkuiri, dan proses pembelajaran mendorong terbentuknya pola pikir yang komprehensif dan luas dengan meginternalisasikan keunggulan, dan kearifan lokal daerah. Untuk dapat memenuhi hal tersebut maka perlu tersedianya perangkat pembelajaran yang terintegrasi dengan kearifan lokal.

Perangkat pembelajaran yang dikembangakan, menggunakan model inkuri yang di integrasikan dengan kearifan local. Corlu \& Corlu, (2012) Model pembelajaran inkuri merupakan model pembelajaran yang dapat membatu pebelajar mengembagkan keterampilan berpikri kritis dan membangun pengetahuan, serta menempatkan mereka seperti ilmuan sesunggunya, (Asy'ari, Ikhsan, \& Muhali, 2019) dengan tujuan untuk mengekspos siswa dengan pengalaman ilmiah melalui pertanyaan, membangun hipotesis sebagai tanggapan atas pertanyaan, dan menguji hipotesis berdasarkan data untuk membentuk pemahaman yang mendalam tentang pengetahuan. Kuhlthau \& Todd, (2007) melalui pembelajaran dengan strategi penyelidikan, siswa dapat membagun sediri pengetahuan, sehingga mereka dapat melakukan pembelajara mandiri dalam masalah yang berkaitan dengan sains. Abdi, 
(2014) pembelajaran dengan model inkuiri dapat meningkatkan hasil belajar siswa. Selanjutnya Hairida, (2016) pembelajaran sains dengan menggunakan modul berbasis inkuri dapat mengembangkan keterampilan bertanya dan pemikiran kritis siswa. Lebih lanjut Hairida, (2016) tujuan pembelajaran inkuri untuk mengembangkan keterampilan berpikir siswa secara logis, kritis dan sistematis melalui penyelidikan tentang sains, fakta, konsep dan prinsip.

Integrasi kearifan local dalam perangkat pembelajaran inkuri merupakan suatu inovasi yang memberikan kesempatan kepada mahasiswa untuk mengelaborasi, mengkritisi, dan mengembangkan self regulation sebagai bagian dari berpikir kritis. Pengintegrasian kearifan local dalam pembelajaran dapat menstimulus motivasi, dan mempermudah mahasiswa dalam mengembangkan keterampilan berpikir kritis (Oktavia, Usmedi, \& Yohandri, 2018). Pengintegrasian kearifan local dalam kurikulum dapat menjaga keutuhan dan kelestarian adat dan budaya masyarakat baik hubungan dengan manusia maupun dengan lingkungan (Adrian, Kortowagiran, \& Hadi, 2018). Hunaepi,dkk (2018) menyatakan bahwa dengan mengintegrasikan nilai-nilai kearifan lokal kedalam pembelajaran akan membuat peserta didik memiliki rasa cinta terhadap budaya lokal serta dapat membentuk peserta didik yang berkarakter, mampu membagkitkan rasa ingin tahu, keinginan untuk memecahkan masalah melaui proses berpikir.

Kearifan lokal yang diintegrasikan kedalam perangkat pembelajaran adalah kearifan-kearifan lokal yang ada di wilayah Nusa Tenggara Barat (NTB) seperti rowot sasak. Rowot sasak adalah kalender tradisional yang dikembangkan dan dipedomani oleh masyarakat sasak, masayarakat sasak menpedomani kalender tersebut sebagai acuan penyelenggaraan gawe (pesta), betaletan (bercocok tanam), pembangian musim, arah naga, dan waktu (pengaruh posisi rasi bintang, terhadap peristiwaperistiwa di permukaan bumi (Hunaepi, dkk 2019). Mengintegrasikan kearifan lokal dalam pembelajaran akan membangun karakter rasa ingin tahu, dan kemampuan memecahkan masalah melalui proses berpikir. Selain itu berpikir kritis dapat difasilitasi melalui pemberian fenomenafenomena autentik yang terdapat dalam kehidupan sehari-hari.

Penelitian ini diharapkan menjadi bagian dari usaha untuk mengembangkan keterampilan berpikir keritis dan menanamkan nilai budaya lokal mahasiswa melalui pengintegrasian kearifan lokal dalam perangakat pembelajaran. Berdasarkan uraian di atas, maka tujuan dari penelitian ini adalah untuk mengevaluasi efektivitas perangkat pembelajaran inkuri terintegrasi kearifan lokal dalam meningkatkan keterampilan berpikir keritis mahasiswa

\section{KAJIAN PUSTAKA}

Perangkat pembelajaran inkuri merupakan sekumpulan sumber belajar atau alat pendukung yang berorientasi pada proses saintifik yang memberikan mahasiswa pengalaman ilmiah yang terintegrasi kearifan lokal. Perangkat pembelajaran yang dikembangakan memberikan pengalaman nyata kepada mahasiswa untuk dapat mengkonstruksi pengetahuan melalu proses inkuiri dengan menginternalisasikan nilai-nilai kearifan lokal. Perangkat pembelajaran inkuri yang dimaksud adalah RPS, Skenario Pembelajaran, Buku Ajar, LKM, perangkat tersebut terintegrasi kearifan local. Egen \& Kauchak (2012) Pembelajaran inkuiri sebagai model pengajaran yang dirancang untuk memberikan mahasiswa pengalaman ilmiah, yakni pola pemikiran yang menekankan pada pengajuan pertanyaan, mengembangkan hipotesis untuk menjawab pertanyaan-pertanyaan dan menguji hipotesis dengan data. Lebih lanjut Egen menjelaskan bahwa model penyelidikan dirancang untuk membantu mahasiswa mendapatkan pemahaman mendalam tentang metode ilmiah sambil mengembangkan pemikiran kritis, pengaturan diri, dan pemahaman mereka tentang topik-topik spesifik. Model pembelajaran inkuiri menurut memiliki 6 (enam) sintak dalam kegiatan pembelajarannya seperti dijabarkan pada Tabel 1.

Tabel 1. Fase Model Pembelajaran Inkuiri

\begin{tabular}{|c|c|}
\hline Fase Pembelajaran & Tingkahlaku Guru \\
\hline $\begin{array}{l}\text { Fase } 1 . \text { Gain attention and explain the } \\
\text { inquiry process }\end{array}$ & $\begin{array}{l}\text { - Mempersiapkan siswa untuk belajar dan mendeskripsikan } \\
\text { proses pembelajaran. }\end{array}$ \\
\hline $\begin{array}{l}\text { Fase 2. Present the inquiry problem or } \\
\text { discrepant event }\end{array}$ & - Mempresentasikan situasi permasalahan kepada siswa. \\
\hline $\begin{array}{l}\text { Fase } 3 . \text { Have students formulate } \\
\text { hypotheses to explain the problem or } \\
\text { event }\end{array}$ & $\begin{array}{l}\text { - Mendorong siswa untuk mengajukan pertanyaan tentang } \\
\text { situaasi permasalahan dan menyusun hipotesis yang dapat } \\
\text { menjelaskan apa yang mereka kerjakan. }\end{array}$ \\
\hline
\end{tabular}


Efektifitas Perangat Pembelajaran Inkuiri Terintegrasi Kearifan Lokal Terhadap Keterampilan Berpikir Kritis Mahasiswa (Hunaepi, Laras Firdaus, Taufik Samsuri, Endang Susantini, Raharjo)

\begin{tabular}{lll}
\hline \multicolumn{1}{c}{ Fase Pembelajaran } & \multicolumn{1}{c}{ Tingkahlaku Guru } \\
\hline $\begin{array}{l}\text { Fase 4. Encourage students to collect } \\
\text { data to test the hypothesis }\end{array}$ & $\bullet$ & $\begin{array}{l}\text { Meminta siswa bagaimana mereka dapat mengumpulkan data } \\
\text { untuk menguji hipotesis mereka. Dalam beberapa kasus, dapat } \\
\text { dilakukan eksperimen. }\end{array}$ \\
\hline $\begin{array}{l}\text { Fase 5. Formulate explanations and/or } \\
\text { conclusions }\end{array}$ & $\bullet \begin{array}{l}\text { Meminta siswa merumuskan penjelasan dan membuat } \\
\text { generalisasi. }\end{array}$ \\
\hline $\begin{array}{l}\text { Fase 6. Reflect on the problem } \\
\text { situation and the thinking processes } \\
\text { used toinquire into it }\end{array}$ & $-\begin{array}{l}\text { Mengajak siswa untuk berpikir tentang proses yang sudah } \\
\text { mereka lalui melakukan refleksi tentang kegiatan inkuiri yang } \\
\text { sudah mereka kerjakan. }\end{array}$ \\
\hline
\end{tabular}

\section{A. Kearifan Lokal}

Kearifan lokal, dapat dipahami sebagai gagasan-gagasan, nilai-nilai, pandangan-pandangan setempat (lokal) yang bersifat bijaksana, penuh kearifan, bernilai baik, yang tertanam dan diikuti oleh anggota masyarakat. (Ibrahin, 2014; Keraf, 2012) mengatakan bahwa kearifan lokal adalah semua bentuk pengetahuan, keyakinan, pemahaman atau wawasan serta adat kebiasaan atau etika yang menuntut prilaku manusia dalam kehidupan di dalam komunitas ekologis. Gobyah (2003) mengatakan kearifan lokal merupakan perpaduan antara nila-nilai suci firman Tuhan dan berbagi nilai yang ada. hal senada dengan pendapat Tarakanita dan Cahyono (2013) kearifan lokal adalah sumber pengetahuan yang diselenggarakan dinamis, berkembangan dan diteruskan oleh populasi tertentu yang terintegrasi dengan pemahaman mereka terhadap alam dan budaya sekitar. Hunaepi, dkk (2016) Kearifan lokal merupakan adalah koleksi fakta, konsep, kepercayaan, dan persepsi masyarakat ihwal dunia sekitar. Ini mencakup cara mengamati dan mengukur alam sekitar, menyelesaikan masalah, dan memvalidasi infomasi

Kearifan lokal dalam konteks penelitian ini tidak terbatas kearifan budaya lokal saja melainkan semua bentuk kearifan yang terdapat di sekitar yang mengadung nilai-nilai kebijakan, yang dapat dijadikan sebagai pedoman pembentukan karakter, sikap, dan keterampilan berpikir keritis mahasiswa. Sehigga dapat dijadikan sebagai pedoman pengembangan karakter, sikap ilmiah dan keterampilan berpikir keritis.

\section{B. Berpikir Kritis}

Keterampilan berpikir kritis merupakan salah satu jenis keterampilan dalam berpikir Paul \& Elder (2011) dan merupakan keterampilan yang penting dalam hidup. Mimbs (2005); Mahapoonyanont (2010); Udi\& Cheng (2015) sehingga mengajarkan ataupun membelajarkannya kepada mahasiswa merupakan suatu yang tidak dapat ditawar lagi, atau dengan lain pernyatan bahwa keterampilan berpikir kritis dalam agenda reformasi/reposisi pendidikan merupakan tujuan pendidikan/pembelajaran (Cotton, 1991; Connie, 2006; Black, 2008; Lai, 2011)

Keterampilan berpikir kritis merupakan keterampilan yang berfokus pada keputusan mengenai apa yang akan dilakukan dan apa yang dipercayai (Udi \& Cheng, 2015). Makna keterampilan berpikir kritis berimplikasi pada suatu pertimbangan yang dilakukan oleh seseorang dalam artian bahwa untuk dapat menentukan pilihan mengenai apa yang akan diakukan dan atau melakukan seperti apa yang ada di dalam benak atau pikirkannya, maka seseorang harus mengenai dan mengevaluasi situsi-situsi yang mungkin terjadi. Ennis (1993) keterampilan berpikir kritis itu meliputi menerapkan informasi pada situasi tertentu, menganalisis sebab munculnya sesuatu atau motif-motif sebab terjadinya sesuatu, dan mengevaluasi ide, pendapat, ataupun argumen seseorang. Facione (2013) menjelaskan bahwa keterampilan berpikir kriti terdiri atas 6 indikator yakni; interpretasi, analisis, kesimpulan, evaluasi, penjelasan dan pengaturan diri. Masing-masing keterampilan berpikir kritis tersebut juga memiliki sub keterampilan serta pertanyaan pertanyaan yang akan mengarahkan individu memiliki kemampuan berpikir krtis.

\section{METODE PENELITIAN}

Populasi dan sampel penelitian ini adalah 100 orang mahasiswa dari empat kelas, pada program studi pendidikan biologi Fakultas Matematika dan Ilmu Pengetahuan Pendidikan IKIP Mataram Indonesia. Penelitian ini adalah penelitian pra eksperimental karena tidak ada kelas control yang dilibatkan sebagai pembanding, dengan menggunakan desain one group pretest dan post-test, yaitu O1 X O2 (Fraenkel at al., 2012). Penelitian ini melibatkan empat kelompok eksperimen, di mana setiap kelas diberi pre-test $(\mathrm{O} 1)$ sebelum mahasiswa mengambil bagian dalam belajar tentang ekologi, dengan 
menggunakan perangkat pembelajaran inkuri terintegrasi kearifan local, berupa Rencana Pembelajaran Semester (RPS), buku ajar eklogi terintegrasi kearifan local, Lembar Kegiatan Mahasiswa (LKM), dan Instrumen Penilaian. Tes keterampilan berpikir kritis yang diberikan kepada siswa dihasilkan dari 6 indikator yang di kembangkan oleh Facione. Tes terhadap Keterampilan berpikir kritis terdiri dari 5 item. Kelima soal tes ini telah dilakukan uji validitas. Validitas secara keseluruhan dari segi isi dan konstruk berkatagori valid dengan rentan skor pada setiap komponen penilain $>3.6$ dengan relibilitas setiap komponen percentage agreement $=100 \%$; 85.7\%; 85.7\%; 85.7\%; dan 100\% (Hunaepi, at.al., 2018).

Perangkat pembelajaran inkuiri terintegrasi kearifan lokal, selanjutnya diimplemnetasikan dalam 4 kelompok eksperimen (X) setelah pre-test diberikan. Pada akhir pembelajaran atau perlakuan, empat kelompok mahasiswa diberikan post-tes $(\mathrm{O} 2)$.

Keterampilan berpikir kritis ini dihitung secara deskriftif menggunakan rumus berikut:

Skor akhir $(\mathrm{K})=[($ Skor diperoleh / skor item maksimum $) \mathrm{x}$ skor maksimum $]$

Perubahan skor dalam tes keterampilan berpikir kritis dihasilkan melalui perhitungan rumus persamaan n-gain seperti yang disarankan oleh (Hake, 1999):

$$
\mathrm{n} \text {-gain }=[(\text { Scoreposttest }- \text { Scorepretest }) /(\text { Scoremaximum-Scorepretest })]
$$

Hasil setelah memiliki perhitungan persamaan n-gain selanjutnya dikonversi menjadi tiga kategori: tinggi $(>0,70)$, sedang $(0,30-0,70)$, dan rendah $(<0,30)$.

Analisis inferensial digunakan untuk menguji efektivitas perangkat pembelajaran inkuiri terintegrasi kearifan lokal dengan melihat peningkatan mahasiswa mengenai keterampiab berpikir kritis dalam tahap implementasi. Hasil pre-test dan post-test dianalisis lebih lanjut secara statistik. Analisis mengenai signifikansi dalam peningkatan hasil pre-test dan post-test dilakukan setelah memiliki tes prasyarat, yaitu uji normalitas data dan uji homogenitas varians yang dilakukan dengan menggunakan perangkat lunak (IBM SPSS Statistik 23).

Pengujian normalitas data (pre-test dan post-test) dilakukan dengan menerapkan uji satu sampel Kolmogorov-Smirnov Z. Data yang terdistribusi normal dianalisis lebih lanjut dengan menggunakan uji-t berpasangan (parametrik), sedangkan yang tidak berdistribusi normal dianalisis menggunakan uji Wilcoxon (non-parametrik) untuk menentukan peningkatan keterampilan berpikir kritis mahasiswa setelah pembeajaran menggunakan perangkat pembelajaran inkuiri terintegrasi kearifan lokal. Dalam mengukur tingkat konsistensi terhadap dampak penerapan perangkat pembelajaran inkuiri terintegrasi kearifan lokal terhadap keterampilan berpikir kritis mahasiswa, penelitian ini menerapkan analisis varian (ANOVA). Metode pemeriksaan tergantung pada hasil yang sesuai dengan asumsi yang dihasilkan dalam uji normalitas dan uji homogenitas varian n-gain.

\section{HASIL DAN PEMBAHASAN}

Skor pe-test dan skor post-test keterampilan berpikir kritis mahasiswa secara umum pada empat kelompok selama ujicoba disajikan pada Gambar 1.

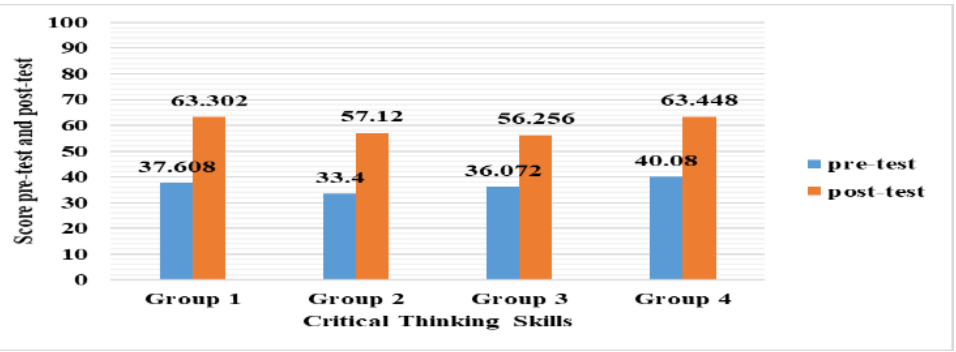

Gambar 1. Skor pe-test dan skor post-test keterampilan berpikir kritis mahasiswa.

Berdasarkan Gambar 1 dapat diketahui bahwa keterampilan berpikir kritis mahasiswa secara umum meningkat setelah pembelajaran menggunakan perangkat pembelajaran yang dikembangkan. 
Efektifitas Perangat Pembelajaran Inkuiri Terintegrasi Kearifan Lokal Terhadap Keterampilan Berpikir Kritis Mahasiswa (Hunaepi, Laras Firdaus, Taufik Samsuri, Endang Susantini, Raharjo)

Skor rata-rata pre-test, post-test, dan n-gain untuk setiap kelompok mahasiswa secara ringkas disajikan pada Tabel 1 dan Gambar 2.

Tabel 1. Skor rata-rata pre-test, post-test, dan n-gain keterampilan berpikir kritis mahasiswa

\begin{tabular}{|c|c|c|c|c|c|c|c|}
\hline \multirow[b]{2}{*}{$\begin{array}{c}\text { Grou } \\
\text { p }\end{array}$} & \multirow{2}{*}{$\begin{array}{l}\text { Number of } \\
\text { prospectiv } \\
\text { e teachers }\end{array}$} & \multirow[b]{2}{*}{ Score } & \multicolumn{5}{|c|}{ Critical thinking skills indicators } \\
\hline & & & $\begin{array}{c}\text { Analysi } \\
\text { s }\end{array}$ & $\begin{array}{c}\text { Evaluatio } \\
n\end{array}$ & $\begin{array}{c}\text { Explanatio } \\
n\end{array}$ & $\begin{array}{c}\text { Interpretati } \\
\text { on }\end{array}$ & $\begin{array}{c}\text { Infere } \\
\text { nce }\end{array}$ \\
\hline \multirow{3}{*}{$\begin{array}{c}\text { Group } \\
1\end{array}$} & \multirow{3}{*}{25} & Pre-test & 60.0 & 36.8 & 38.8 & 32.4 & 32.4 \\
\hline & & $\begin{array}{c}\text { Post- } \\
\text { test }\end{array}$ & 82.4 & 63.2 & 68.8 & 66.0 & 67.2 \\
\hline & & n-gain & 0.56 & 0.42 & 0.49 & 0.49 & 0.51 \\
\hline \multirow{3}{*}{$\begin{array}{c}\text { Group } \\
2\end{array}$} & \multirow{3}{*}{25} & Pre-test & 38.4 & 40.0 & 33.6 & 37.2 & 28.8 \\
\hline & & $\begin{array}{l}\text { Post- } \\
\text { test }\end{array}$ & 79.2 & 58.4 & 57.6 & 58.8 & 62.0 \\
\hline & & n-gain & 0.66 & 0.30 & 0.36 & 0.34 & 0.47 \\
\hline \multirow{3}{*}{$\begin{array}{c}\text { Group } \\
3\end{array}$} & \multirow{3}{*}{25} & Pre-test & 51.2 & 34.4 & 41.6 & 34.0 & 30.4 \\
\hline & & $\begin{array}{l}\text { Post- } \\
\text { test }\end{array}$ & 81.6 & 54.4 & 60.8 & 53.6 & 58.4 \\
\hline & & n-gain & 0.62 & 0.30 & 0.32 & 0.30 & 0.40 \\
\hline \multirow{3}{*}{$\underset{4}{\text { Group }}$} & \multirow{3}{*}{25} & Pre-test & 53.6 & 43.6 & 40.4 & 41.2 & 37.2 \\
\hline & & $\begin{array}{c}\text { Post- } \\
\text { test }\end{array}$ & 84.8 & 66.8 & 68.8 & 64.0 & 66.0 \\
\hline & & n-gain & 0.67 & 0.41 & 0.44 & 0.38 & 0.46 \\
\hline
\end{tabular}

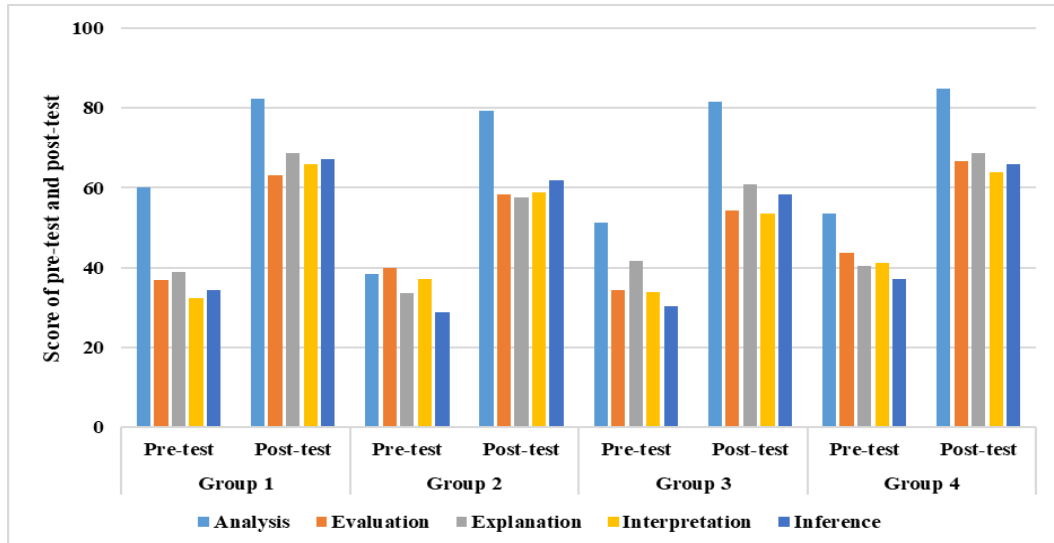

Gambar 2. Skor pre-test dan skor post-test keterampilan berpikir kritis mahasiswa berdasarkan indikator

Tabel 1 dan Gambar 2 menunjukkan bahwa rata-rata skor pre-test dan post-test semua kelompok mengalami peningkatakan setelah pembelajaran menggunakan perangkat pembelajaran yang dikembangkan pada setiap indikator keterampilan berpikir kritis. Indikator analisis $(n$-gain $=0.63)$ dan inferensi $(n$-gain $=0.46)$ secara rata-rata n-gain untuk semua kelompok menjadi indikator keterampilan berpikir kritis yang mengalami peningkatan yang paling tinggi setelah pembelajaran meskipun secara umum n-gain setiap indikator keterampilan berpikir kritis masih dalam kategori sedang.

Penentuan distibusi skor per-test dan post-test keterampilan berpikir kritis mahasiswa dianalisis menggunakan one-sample Kolmogorov-Smirnov $Z$ test menggunakan IBM SPSS Statistics 22 software. Hasil uji dstribusi data keterampilan berpikir kritis mahasiswa pada Tabel 2.

Tabel 2. Distribusi data pre-test dan post-test keterampilan berpikir kritis mahasiswa.

\begin{tabular}{|c|c|c|c|c|c|c|}
\hline \multirow[t]{2}{*}{ Group } & \multirow[t]{2}{*}{ Score } & \multirow[t]{2}{*}{$\mathbf{N}$} & \multicolumn{4}{|c|}{ Critical thinking skills } \\
\hline & & & Mean & Std. Deviation & $\mathbf{p}$ & Normal Distribution \\
\hline \multirow[t]{2}{*}{1} & Pre-test & 25 & 37.60 & 8.14 & .865 & Yes \\
\hline & Post-test & 25 & 63.03 & 7.79 & .676 & Yes \\
\hline \multirow[t]{2}{*}{2} & Pre-test & 25 & 33.40 & 6.42 & .810 & Yes \\
\hline & Post-test & 25 & 57.12 & 7.08 & .998 & Yes \\
\hline \multirow[t]{2}{*}{3} & Pre-test & 25 & 36.07 & 7.95 & .988 & Yes \\
\hline & Post-test & 25 & 56.25 & 8.22 & .691 & Yes \\
\hline \multirow[t]{2}{*}{4} & Pre-test & 25 & 40.08 & 6.60 & .600 & Yes \\
\hline & Post-test & 25 & 63.44 & 7.69 & .975 & Yes \\
\hline
\end{tabular}


Tabel 2 menunjukkan bahwa skor pre-test dan post-test keterampilan berpikir kritis mahasiswa >alpa pengujian (0.05) sehingga dapat dinyatakan bahwa skor pre-test dan post-test keterampilan berpikir kritis mahasiswa berdistribusi normal. Pair t-test dilakukan untuk menentukan efektifitas perangkat pembelajaran yang dikembangkan dalam meningkatkan keterampilan berpikir kritis mahasiswa. Hasil pair t-test keterampilan berpikir kritis mahasiswa pada semua kelaompok disajikan pada Tabel 3.

Tabel 3. Hasil pair t-test keterampilan berpikir kritis mahasiswa pada semua kelompok

\begin{tabular}{ccccccc}
\hline Pair & $\mathbf{N}$ & \multicolumn{6}{c}{ Critical thinking skills } \\
\cline { 3 - 7 } & & Mean & Std. Error Mean & t & df & p \\
\hline Pair 1 & 25 & 50.45 & 2.39 & 10.61 & 24 & .000 \\
\hline Pair 2 & 25 & 45.26 & 1.91 & 12.39 & 24 & .000 \\
\hline Pair 3 & 25 & 46.16 & 2.12 & 9.49 & 24 & .000 \\
\hline Pair 4 & 25 & 51.76 & 2.20 & 10.61 & 24 & .000 \\
\hline
\end{tabular}

Berdasarkan Tabel 3, dapat diketahui bahwa keterampilan berpikir kritis mahasiswa sebelum dan setelah pembelajaran menggunakan perangkat yang dikembangkan dinyatakan berbeda nyata $(\mathrm{p}<$ 0.05). Hasil tersebut menunjukkan bahwa perangkat pembelajaran yang dikembangkan efektif untuk meningkatkan keteremapilan berpikir kritis mahasaiswa.

Konsistensi dampak penggunaan perangkat pembelajaran yang dikembangkan terhadap keterampilan berpikir kritis mahasiswa diuji menggunakan uji ANOVA seperti disajikan pada Tabel 4.

Tabel 4. Hasil uji ANOVA keterampilan berpikir kritis mahasiswa pada semua kelompok

\begin{tabular}{lrrrrr}
\hline & Sum of Squares & df & Mean Square & \multicolumn{1}{c}{ F } & \multicolumn{1}{c}{ Sig. } \\
\hline Between Groups & 1084.712 & 3 & 361.571 & 6.081 & .001 \\
Within Groups & 5707.638 & 96 & 59.455 & & \\
Total & 6792.350 & 99 & & & \\
\hline
\end{tabular}

Tabel 4 menunjukkan bahwa peningkatan keterampilan berpikir kritis mahasiswa berbeda nyata pada setiap kelompok $(\mathrm{p}<0.05)$. berdasarkan hasil tersebut, less significant different (LSD) test dilakukan untuk mengetahui pada kelompok apa saja yang mengalami perbedaan dampak penggunaan perangkat pembelajaran yang dikembangkan. Hasil uji LSD disajikan pada Tabel 5.

Tabel 5. Hasil Uji LSD keterampilan berpikir kritis mahasiswa pada semua kelompok.

\begin{tabular}{rlrrrrr}
\hline & & $(\mathrm{J})$ & & & \multicolumn{2}{c}{ 95\% Confidence Interval } \\
\cline { 5 - 7 }$(\mathrm{I})$ group & group & Mean Difference $(\mathrm{I}-\mathrm{J})$ & Std. Error & Sig. & Lower Bound & Upper Bound \\
\hline 1 & 2 & $5.91200^{*}$ & 2.18091 & .008 & 1.5829 & 10.2411 \\
& 3 & $6.77600^{*}$ & 2.18091 & .002 & 2.4469 & 11.1051 \\
& 3 & -.41600 & 2.18091 & .849 & -4.7451 & 3.9131 \\
& 4 & $-5.91200^{*}$ & 2.18091 & .008 & -10.2411 & -1.5829 \\
& 1 & .86400 & 2.18091 & .693 & -3.4651 & 5.1931 \\
& 3 & $-6.32800^{*}$ & 2.18091 & .005 & -10.6571 & -1.9989 \\
3 & 4 & $-6.77600^{*}$ & 2.18091 & .002 & -11.1051 & -2.4469 \\
& 1 & -.86400 & 2.18091 & .693 & -5.1931 & 3.4651 \\
& 1 & $-7.19200^{*}$ & 2.18091 & .001 & -11.5211 & -2.8629 \\
& 2 & .41600 & 2.18091 & .849 & -3.9131 & 4.7451 \\
4 & 4 & $6.32800^{*}$ & 2.18091 & .005 & 1.9989 & 10.6571 \\
& 1 & $7.19200^{*}$ & 2.18091 & .001 & 2.8629 & 11.5211 \\
\hline
\end{tabular}

Tabel 5 menunjukkan bahwa keterampilan berpikir kritis mahasiswa pada semua kelompok tidak berbeda nyata pada Group 1 dengan Group 4 dan Group 2 dengan Group 3 pada taraf signifikansi 0.05 .

\section{Pembahasan}

Berpikir kritis adalah proses mencari, memproduksi, mengevalusi, menganalisis, mensintesis dan mengkonseptualkan informasi sebagai panduan pengembangan keterampilan berpikir seseorang dengan kesadaran dan kemampuan menggunakan informasi itu secara kreatif, (Fitriani, et., al, 2018) sehingga dapat memfilter antara pengetahuan yang relevan dan tidak releva untuk dapat mengambil keputusan yang tepat (Hadi, et.,al, 2018). Hasil penelitian menunjukkan bahwa perangkat pembeajaran model inkuiri terintegrasi kearifan local, setelah diimplementasikan efetif dalam meningkatkan 
Efektifitas Perangat Pembelajaran Inkuiri Terintegrasi Kearifan Lokal Terhadap Keterampilan Berpikir Kritis Mahasiswa (Hunaepi, Laras Firdaus, Taufik Samsuri, Endang Susantini, Raharjo)

keterampilan berpikir kritis mahasiswa dalam pembelajaran ekologi. Adapun keefektifan diperlihatikan seperti pada hasil analisis 1) peningkatan skor dari pre-test ke post-test, 2) skor N Gain keterampilan berpikir kritis mahasiswa pada setiap indicator secara umum masih dalam katagori sedang, keculai pada indicator analisis $(n$-gain $=0.63)$ dan inferensi $(n$-gain $=0.46)$ mengalami peningkatan yang paling tinggi, 3) skor Pair t-test dilakukan untuk menentukan efektifitas keterampilan berpikir kritis mahasiswa sebelum dan setelah pembelajaran menggunakan perangkat yang dikembangkan dinyatakan berbeda nyata $(\mathrm{p}<0.05)$. Hasil tersebut menunjukkan bahwa perangkat pembelajaran yang dikembangkan efektif untuk meningkatkan keteremapilan berpikir kritis mahasaiswa, dan 4) hasil uji konsistensi menggunakan ANOVA menunjukkan bahwa peningkatan keterampilan berpikir kritis mahasiswa berbeda nyata pada setiap kelompok ( $<<0.05)$, akan tetapi tidak berbeda nyata pada Group 1 dengan Group 4 dan Group 2 dengan Group 3 pada taraf signifikansi 0.05. setelah di uji menggunakan LSD.

Rendahnya hasil pre-test menunjukkan bahwa kemampuan mahasiswa dalam meyelesaikan soal-soal yang melibatkan keterampilan berpikir kritis masih rendah, hal ini disebabkan karena perangkat pebelajaran yang dirancang dan diterapkan oleh dosen belum mendukung upanya mengembangkan keterampilan berpikir kritis mahasiswa. (Hunaepi, et.at, 2018) Rendahnya keterampilan berpikir kritis mahasiwa disebabkan adanya proses pembelajaran yang masih menekankan pada peningkatan kemampuan kognitif dan kurang membiasakan mahasiswa untuk mengembangkan keterampilan berpikir kritis. Lebih lanjut (ECD PISA, 2013; Fazriyah, Supriyanti, \& Rahayu, 2017; Kemendikbud, 2017) keterampilan berpikir kritis siswa masih lemah karena proses pembelajaran yang berlansung masih berorientasi pada kemampuan kognitif.

Peningkatan skor keterampilan berpikir kritis setelah pembelajaran ekologi dengan perangkat pembelajaran model inkuri terintegrasi kearifan lokal dengan tingkat kenaikan rata-rata dalam kategori sedang, kecuali pada indicator analisis dan inferensi, dan tidak berbeda untuk ke empat kelompok. (Slavin, 1994) keterlibatan aktif siswa dalam pembelajaran inkuri dapat meningkatkan retensi informasi dalam memori jangka panjang, sehingga meningkatkan kemampuan penguasaan konsep materi, (Azizmalayeri, et al., 2012) dan memberikan efek posistif terhadap peningkatan keterampilan berpikir keritis dan inferensi. Model pembelajaran inkuri berfokus pada proses berpikir yang membangun pengalama dengan dengan melibatkan mahasiswa secara aktif dalam pembelajaran. Peningkatan keterampilan berpikir kritis mahasiswa tidak lepas dari peranan perangkat pembelajaran yang dikembangkan (Kuhlthau \& Todd, 2007). (Khasanah \& Abdulla, 2016) cientific inquiry dapat meningkatan keterampilan berpikir kritis siswa dari pada penggunaan pendekatan konvensional, selain itu. (Gularso, Lukitoaji \& Noormiyanto, 2017) menyatakan bahwa model pembelajaran berbasis local wisdom dan local genius efektif meningkatkan keterampilan berfikir kritis. Implementasi pembelajaran sains berdasarkan kearifan lokal tidak hanya meningkatkan karater positif, tetapi juga meningkatkan prestasi belajar siswa (Subali, Sopyan \& Ellianawati, 2015; Ayu, dkk, 2017).

Pengintegrasian kearifan lokal dalam perangkat pembelajaran memberikan kesempatan kepada mahasiswa untuk melakukan eksplorasi pengetahuan dengan menghubungkan konsep-konsep dengan kehidupan sehari-hari. Penggunaan kearifan lokal dalam perangkat pembelajaran dapat membantu pebelajar memahami konsep secara kontekstual dan benar, melalui kearifan lokal pebelajar dapat belajar nilai-nilai budaya dan rasa nasionalisme yang dapat mempengaruhi sikap, perilaku, dan keterampilan berpikir (Laurens, et.al., 2014). Selain itu pembelajaran akan lebih bermakna dalam artian mahasiswa dapat memahami secara utuh materi yang dipelajari. Ausubel belajar dikatakan menjadi bermakna apabila informasi yang akan dipelajari siswa disusun sesuai dengan struktur kognitif yang dimiliki siswa, sehingga mampu mengaitkan informasi barunya dengan struktur kognitif yang dimilikinya (Hunaepi, dkk., 2020).

Karakteristik utama dari perangkat pembelajaran inkuiri terintegrasi kearifan lokal yang dikembangkaan antara lain 1) tujuan pembelajaran dalam RPS spesifik berorientasi pada keterampilan berpikir kritis dan terintegrasi kearifan lokal, 2) Buku ajar yang dikembangkan terintegrasi kearifan lokal dan berorientasi mengembangkan kognitif produk dan kognitif proses yakni keterampilan berpikir kritis, 3) lembar kerja mahasiswa terintegrasi kearifan lokal dan berorietasi metode ilmiah yang dapat mempasilitasi keterampilan berpikir kritis, dan 4) tes yang dikembangkan berdasarakan indikatorindikator berpikir kritis, sehingga dapat mengevaluasi peningkatan berpikir kritis mahasiswa. 
Berdasarkan hasil dan diskusi, perlu untuk memberikan penekanan pada peningkatan keterampilan berpikir kritis pada indikator-indikator evaluasi, explanation, interpretation dengan mengembangkan model inkuiri yang terintegrasi dengan kearifan local.

\section{SIMPULAN DAN SARAN}

Temuan penelitian menunjukkan bahwa keterampilan berpikir kritis mahasiswa sebelum dan setelah pembelajaran menggunakan perangkat yang dikembangkan dinyatakan berbeda nyata $(\mathrm{p}<$ 0.05). Hasil tersebut menunjukkan bahwa perangkat pembelajaran yang dikembangkan efektif untuk meningkatkan keteremapilan berpikir kritis mahasaiswa. Indikator analisis $(n$-gain $=0.63)$ dan inferensi $(n$-gain $=0.46)$ secara rata-rata $n$-gain untuk semua kelompok menjadi indikator keterampilan berpikir kritis yang mengalami peningkatan yang paling tinggi setelah pembelajaran meskipun secara umum ngain setiap indikator keterampilan berpikir kritis masih dalam kategori sedang. Meskipun dinyatakan efektif masih perlu penyempurnaan dengan dilakukan pengembangan model inkuiri yang terintegrasi dengan kearifan lokan.

\section{UCAPAN TERIMAKASIH}

Kegiatan penelitian ini, di biayai oleh kemenristekdikti, melalui program hibah penelitian kerjasama perguruan tinggi (PKPT). Pihak lain yang mendukung kegiatan penelitian PKPT ini adalah Universitas Pendidikan Mandalika dan Universitas Negeri Surabaya. Selain itu program studi pendidikan biologi FSTT UNDIKMA yang telah bersedia menjadi mitra implementasi kegiatan penelitian ini.

\section{DAFTAR PUSTAKA}

Alghamdi, A. K. H., and Hassan, N. A. S. 2016. The Effectiveness of the Mawhiba Program for the Development of Critical Thinking Skill among Gifted Female Students at Secondary Levels. British Journal of Education Society \& Behavioural Science, 14(2), 113. DOI: 10.9734/BJESBS/2016/20367

Ayu A. Kurniawati, Sri Wahyuni, and Pramudya D. A. Putra. (2017) Utilizing of comic and jember's local wisdom asintegrated science learning materials. International Journal of Social Science and Humanity, Vol. 7, No. 1. 47-50. doi: 10.18178/ijssh.2017.7.1.793

Andrian D., Kartowagiran B., \& Hadi S. (2018). The Instrument Development to Evaluate Local Curriculum in Indonesia. International Journal of Instruction, 11(4), 921934.https://doi.org/10.12973/iji.2018.11458a.

Abdi A., (2014). The Effect of Inquiry-based Learning Method on Students' Academic Achievement in Science Course. Universal Journal of Educational Research 2(1): 37-41. DOI: 10.13189/ujer.2014.020104

Azizmalayeri, K., Jafar, E., M., Sharif, M., Asgari, M., and Omidis, M. (2012) The impact of guided inquiry methods of teaching on the critical thinking of high school students. Journal of Education and Practice, 3(10), 42-47.

https://www.iiste.org/Journals/index.php/JEP/article/viewFile/2530/2546

Asy'ari, M., Ikhsan, M., \& Muhali (2019). The Effectiveness of Inquiry Learning Model in Improving Prospective Teachers' Metacognition Knowledge and Metacognition Awareness. International Journal of Instruction, 12(2), 455-470.https://doi.org/10.29333/iji.2019.12229a

Amin, M.A., Corebima, D.A., Zubaidah, S. and Mahanal, S. (2017)The Critical Thinking Skills Profile of Preservice Biology Teachers in AnimPhysiology. Advances in Social Science, Education and Humanities Research, volume 128. 3rd International Conference on Education and Training. Published by Atlantis Press.

A Partnership for 21st Century Skills 2015 Framework Definitions P21 (Washington, DC: APartnership for 21st Century Skills) 
Efektifitas Perangat Pembelajaran Inkuiri Terintegrasi Kearifan Lokal Terhadap Keterampilan Berpikir Kritis Mahasiswa (Hunaepi, Laras Firdaus, Taufik Samsuri, Endang Susantini, Raharjo)

Black, B (2008). Critical Thinking a Definition and Taxonomy for Cambridge Assessment: Supporting Validity Arguments About Critical Thinking Assessment Administrated. International Association of Educational Assessment Annual Conference (pp. 1 - 12). Cambridge: Cambridge University

Bassham, G., Irwin, W., Nardone, H., Wallace, J.(2011). Critical Thinking: A Student's Introduction.NewYork;McGraw-Hill.

Black, B (2008). Critical Thinking a Definition and Taxonomy for Cambridge Assessment: Supporting Validity Arguments About Critical Thinking Assessment Administrated. International Association of Educational Assessment Annual Conference (pp. 1 - 12). Cambridge: Cambridge University

Cotton, K (1991). Teaching Thinking Skills. School Improvement Research Series (SIRS), 1 -19.

Lai, R., E (2011). Critical Thinking: A Literature Review. London: Pearson https://images.pearsonassessments.com/images/tmrs/CriticalThinkingReviewFINAL.pdf

Connie, S (2006). Approaches to Evaluate Critical Thinking Dispositions. APERA Conference (1 - 8). Hong Kong: Hong Kong.

Changwong, K., Sukkamart, A., \& Sisan, B. (2018). Critical thinking skill development: Analysis of a new learning management model for Thai high schools. Journal of International Studies, 11(2), 37-48. doi:10.14254/20718330.2018/11-2/3

Corlu, M.A., \& Corlu, M.S. (2012). Scientific Inquiry Based Professional Development Models In Teacher Education. Educational Sciences: Theory \& Practice. 12(1), 514521.https://files.eric.ed.gov/fulltext/EJ978456.pdf

Cekin A., (2015). The Investigation of Critical Thinking Dispositions of Religious Culture and Ethics Teacher Candidates (The Case of Ankara University and Kastamonu University in Turkey). Journal of Education and Learning. Vol.9 (2) pp. 158-164. file:///C:/Users/ACER/AppData/Local/Temp/1718-3881-1-PB.pdf

Eggen, P., \& Kauchak, D. (2012). Strategies and Models for Teachers: Teaching Content and Thinking Skills (6th ed.). Boston: Pearson.

Ennis R (1993) Critical thinking assessment. Theory into practice 323 Ohio state university: colof education

ECD PISA 2013 Snapshot of Student Performance in Mathematics Reading and Science (OECD Publishing)

Fraenkel, J., Wallen, N., \& Hyun, H. (2012). How to design and evaluate research in education $\left(8^{\text {th }}\right.$ edt.). New York: McGram-Hill Companies: Inc.

Facione, P.A. (2013). Critical Thinking: What It Is and Why It Counts. Millbrae, CA: Measured Reasons and The California Academic Press.

Fazriyah N., Supriyanti Y., and Rahayu W., (2017) The Effect of Integrated Learning Model and Critical Thinking Skill of Science Learning Outcomes. IOP Conf. Series: Journal of Physics: Conf. Series 812 (2017) 012014 doi:10.1088/1742-6596/812/1/012014

Fitrini., H., Asy'ari, M., Zubaidah, S., and Mahanal, S., (2019) Exploring the Prospective Teachers' Critical Thinking and Critical Analysis Skills. Jurnal Pendidikan IPA Indonesia. 8 (3), 379-390. DOI: 10.15294/jpii.v8i3.19434

Fitrini., H., Asy'ari, M., Zubaidah, S., and Mahanal, S.,(2018) Critical Thinking Disposition of ProspectiveScienceTeachers at IKIP Mataram, Indonesia. IOP Conf. Series: Journal of Physics: Conf. Series 1108 (2018) 012091 doi :10.1088/1742-6596/1108/1/012091

Faradia. R., Fuzi., dan Vitoria, L. (2017) pengaruh kemampuan berpikir kritis terhadap belajar matematika siswa kelas V SDN 3 Banda Aceh. Jurnal Ilmiah Pendidikan Guru Sekolah Dasar FKIP Unsyiah Volume 2 Nomor 4, 119-126 
Gularso D., Lukitoaji D.B., dan Noormiyanto F., (2017) Efektifitas penggunaan model pembelajaran pendidikan Kebudayaan daerah berbasis local genius, local wisdom, dan Riset ditinjau dari keterampilan berpikir kritis calon guru Sekolah dasar. Jurnal Bidang Pendidikan Dasar (JBPD) Vol. 1 No. 1. Hal 1-10. doi :https://doi.org/10.21067/jbpd.v1i1.1600

Hairida, (2016) the effectiveness using inquiry based natural science Module with authentic assessment to improve the Critical thinking and inquiry skills of junior high School students. Jurnal Pendidikan IPA Indonesia, 5 (2) (2016) 209-215. DOI: 10.15294/jpii.v5i2.7681

Hunaepi, Firdaus L., Samsuri T., Susnatini E., dan Raharjo (2020) Implementasi Worksheet Inkuiri Terintegrasi Kearifan Lokal Untuk Meningkatkan Keterampilan Berpikir Kritis Mahasiswa. Bioscientist : Jurnal Ilmiah Biologi. 8(1) 158-169.

Hunaepi, Susantini E., Firdaus, L.,Samsuri, T., and Raharjo, (2018) Validitas Perangkat Pembelajaran Model Inkuiri Terintegrasi Kearifan Lokal Untuk Melatih Keterampilan Berpikir Kritis Dan Disposisi Berpikir Kritis Mahasiswa. Judika (Jurnal Pendidikan Unsika). 6 (2) 47-58. http://journal.unsika.ac.id/index.php/judika

Hunaepi, Kurnia. N., dan Firdaus. F., (2016) Mapping of Local Wisdom of West Nusa Tenggara to Developing Ecology Textbook. International Conference on Elementary and Teacher Education (ICETE) 2016. Hal. 250-255.

Hunaepi, Susantini E., Raharjo, Samsuri T., dan Firdaus L., (2019) Buku Ajar Ekologi Terintegrasi Kearifan Lokal. LITPAM. Mataram

Hadi S.A., Susantini E., and Agustini R. (2018) Training of Students' Critical Thinking Skills through the implementation of a Modified Free Inquiry Model. OP Conf. Series: Journal of Physics: Conf. Series 947 (2018) 012063 doi :10.1088/1742-6596/947/1/012063

Ibrahim, M. 2014. Inovasi Pembelajaran Sains Berbasis Kearifan Lokal. Makalah Disampaikan pada Seminar Nasional FPMIPA IKIP MATARAM 2014. Makalah Prosiding hal.xv -xxiv

Irwan, I., Maridi, M., \& Dwiastuti, S. (2019). Developing guided inquiry-based ecosystem module to improve students' critical thinking skills. JPBI (Jurnal Pendidikan Biologi Indonesia), 5 (1), 51-60. doi: https://doi.org/10.22219/jpbi.v5i1. 7287

Kuhlthau \& Todd. 2007. Guided Inquiry: A framework for learning through school librariesin 21st century schools. New Jersey: CISSL.

Khasanah, U., and Abdulla, W., (2016) Scientific Inquiry for Critical Thinking Ability and SelfConfidence Islamic Junior High School of Students. International Conference on Mathematics, Science, and Education, 176-179.

Kemendikbud 2011 Survei International PISA (Programme for International Student Assessment) (Jakarta: Kemendikbud)

Komariyah. S., Laili, N.F.A (2018) pengaruh kemampuan berpikir kritis terhadap hasil belajar matematika. Jurnal Penelitian Pendidikan dan Pengajaran Matematika. vol. 4 no. 2, pp. 55-60

Keraf, S.A. 2002. Etika Lingkungan. Penerbit Buku Kompas. Jakarta

Kuhlthau \& Todd. 2007. Guided Inquiry: A framework for learning through school librariesin 21st century schools. New Jersey: CISSL.

Murawski, L.M, (2014) Critical Thinking in the Classroom...and Beyond. Journal of Learning in Higher Education. 10(1), 25-30.

Mulyanto, H., Gunarhadi, Indriayu,M. (2018). The effect of problem based learning model on student mathematics learning outcomes viewed from critical thinking skills.International Journal of Educational Research Review,3(2),37-45

Mimbs, C (2005). Teaching From The Critical Thinking Problem Based Curricular Approach: Strategies, Challenges and Recomendation. Journal of Familiy and Consumer Science Education, Vol. 23, Number. 2, 7 - 18. 
Efektifitas Perangat Pembelajaran Inkuiri Terintegrasi Kearifan Lokal Terhadap Keterampilan Berpikir Kritis Mahasiswa (Hunaepi, Laras Firdaus, Taufik Samsuri, Endang Susantini, Raharjo)

Mahapoonyanont, N (2010). Faktors Related to Critical Thinking Abilities: A Meta Analysis. Procedia Social and Behavioral Sciences, 986 - 990

Masek, A., \& Yamin, S. (2011). The Effect of Problem Based Learning on Critical Thinking Ability: A Theoretical and Empiric al Review. International Review of Social Science and Humanities, 2(1), 215-221

Oktavia, I., R., Usmeldi., \& Yohandri, (2018) Development of Physics Learning Material Based on Problem Based Learning by Integrating Local Wisdom West Sumatra to Improve Critical Thinking Ability of Students. International Journal of Progressive Sciences and Technologies, 6(2), 544-553.

Paul, R \& Elder, L (2011). Consequential Validity: Using Assessment to Drive Instruction. Foundation for Critical Thinking, $1-7$

Rohmawatiningsih, W., Rachman, I., dan Kodama, Y., (2018) Improving Critical Thinking Skills and Environment Caring Attitude Through Integrated Environment-Based Learning Model. Journal of Sustainable Development Education and Research. 2(1), 69-73. DOI:https://doi.org/10.17509/jsder.v2i1.12360

Subali, B, Sopyan, A, Ellianawati (2015) Developing local wisdom based science learning Design to establish positive character in Elementary school. Jurnal Pendidikan Fisika Indonesia 11 (1) (2015) 1-7 DOI: 10.15294/jpfi.v11i1.3998

Slavin RE 1994 Educational Psychology: Theory and Practice, Student Value Edition (8th Edition) (London: Pearson Education)

Sari, R.M., Sumarni, Astina, I., K., \& Utomo, H.,D, (2018) Measuring Students Scientific Learning Perception and Critical Thinking Skill Using Paper-Based Testing: School and Gender Differences. iJET - Vol. 14, No. 19, 2019. https://doi.org/10.3991/ijet.v14i19.10968

Slamet, A., Tapilouw, S.F., Rohman, I., and Adianto (2014) critical Thinking Ability Analysis beginning teacher candidates of biology in The Animal Physiologi Material at biology education program FKIP Sriwijaya University. International journal of science and resear (IJSR). Vol 3 (7).

Taghva, F., Rezaei N., Ghaderi J., \& Taghva (2014). Studying the relationship between critical thinking skills and students' educational achievement (eghlid universities as case study). International Letter of Social and Humanistic Sciences, Volume 25, PP 18-25. https://doi.org/10.18052/www.scipress.com/ILSHS.25.18

Tarakanita.I dan Cahyono.M.Y.M, 2013. Komitmen Identitas Etnik Dalam Kaitannya Dengan Eksistensi Budaya Lokal. Jurnal Zenit, vol 2. No.2. 1-14

Udi, E \& Cheng, D (2015). Developing Critical Thinking Skills from Dispositions to Abilities: Mathematics Education from Early Childhood to High School . Creative Education, 455 - 462

Prayogi, S., Yuanita, L., \& Wasis. (2018). Critical Inquiry Based Learning: A Model of Learning to Promote Critical Thinking Among Prospective Teachers of Physic. Journal of Turkish Science Education, 15(1), 43-56.

Prayogi S, Yuanita L \& Wasis. (2017). Critical Inquiry Based Learning: Model of learning to promote critical thinking ability of pre-service teachers. J. Phys.: Conf. Ser. 947: 1-6

Putra, B.,K., B., Prayitno, B., A., and Maridi. (2018). The Effectiveness of Guided Inquiry and INSTAD Towards Students' Critical Tinking Skills on Circuatory System Materials. Jurnal Pendidikan IPA Indonesia7 (4) 476-482, DOI: 10.15294/jpii.v7i4.14302

Wheelihan, K. J. (2011). Creativity for Success. The Creativity Institute. Retrieved from http://EzineArticles.com/.

Wahyudi, N NSP., Verawati S., Ayub and S Prayog (2018) Development of Inquiry-Creative-Process Learning Modelto Promote Critical Thinking Ability of PhysicsProspectiveTeachers. IOP 
Conf. Series: Journal of Physics: Conf. Series 1108 (2018) 012005 doi :10.1088/1742$6596 / 1108 / 1 / 012005$

Wasis, (2016) Higher OrderThinking Skills (HOTS): Konsep dan Implementasinya.Seminar Nasional PKPSM IKIP Mataram, Mataram

Qolbi, F., Kartimi, \& Roviati, E. (2016). Penerapan Pembelajaran Berbasis Sains Budaya Lokal Ngarot untuk Meningkatkan Keterampilan Berpikir Kritis Siswa pada Konsep Plantae (Studi Eksperimen Kelas X di SMAN 1 Lohbener). Jurnal Sains dan Pendidikan Sains, 5(2), 105-121.

Quitadamo, I., J., Faiola, C.,L., Johnson,J.,E., and Kurtz, M.,J. (2008) Community based Inquiry Improves Critical Thinking in General Education Biology. CBE-Life Sciences Education. 1. (7), 327-337. DOI: 10.1187/cbe.07-11-0097 